\title{
Production Performance of Catfish (Clarias gariepinus Burchell, 1822) Cultured With Added Probiotic Bacillus sp. on Biofloc Technology
}

\author{
Rifqah Pratiwi ${ }^{1 *}$, Kurniawan Wahyu Hidayat ${ }^{2}$ and Sumitro ${ }^{3}$ \\ ${ }^{1}$ Aquaculture Engineering Study Program, Polytechnic of Marine and Fisheries Kupang, Kupang \\ 85351, Indonesia \\ ${ }^{2}$ Aquaculture Study Program, Polytechnic of Marine and Fisheries Pangandaran, Pangandaran \\ 46396, Indonesia \\ ${ }^{3}$ Aquaculture Study Program, Faculty of Fisheries and Marine Sciences, Dayanu Ikhsanuddin \\ University, Baubau 93711, Indonesia
}

\author{
*Correspondence : \\ rifqahpratiwi.ipb@gmail.com
}

Received : 2019-11-26

Accepted : 2020-07-06

Keywords :

Biofloc technology, Catfish, Bacillus sp., Production performance

\begin{abstract}
Biofloc technology (BFT) is one of the most developed aquaculture technologies, which aims to improve the efficiency of feed use by providing nutrients for flocs to be used by fish as a supplementary feed. Also, BFT serves to improve water quality through the breaking down of fish waste materials assisted by heterotrophic bacteria. Bacteria used in this study were Bacillus sp. as probiotics in BFT. This study aimed to examine the production performance of catfish maintained with a biofloc system on an industrial scale, without experimental design. The average weight of catfish when stocking was $5.9 \pm 0.0 \mathrm{~g} /$ fish with a density of 7000 fish in 9 unit circular ponds. This studies showed after 78 days of culture, bodyweight gain about $28.6 \mathrm{~g} /$ fish to $41.7 \mathrm{~g} /$ fish, highest specific growth rate was $\mathrm{K} 2(2.4 \pm 0.2 \% \mathrm{BW} /$ day $)$, the highest survival rate $\mathrm{K} 2(98.87 \pm 6.64 \% \mathrm{BW} /$ day $)$, highest grow rate K1 $(41.7 \pm 5.8 \mathrm{~g})$ and the best FCR K9 $(0.95 \pm 0.11)$.
\end{abstract}

\section{INTRODUCTION}

Catfish production in Indonesia has continued to increase every year. According to DJPB (Aquaculture bureau) data (Direktorat Jenderal Perikanan Budidaya, 2016), the catfish production target in 2016 was 1,217,100 tons and in 2019 catfish production target is $1,770,600$ tons with an average annual increase of $13.75 \%$. Catfish is one of the most popular consumption fish in Indonesia. As an effort to fulfill the catfish production target, there needs to be a technological innovation in culture, one of which is by conducting intensive culture by increasing fish stocking density. On the other hand, an increased fish stocking density could cause the accumulation of uneaten feed, and organic and inorganic materials which become waste material and are toxic for cultured fish, causing stress to fish, which makes them susceptible to diseases such as bacterial, mycological, or viral diseases (Sukenda et al., 2016).

One breakthrough in the catfish aquaculture system to overcome several issues especially in high-stocking density culture is biofloc technology (BFT). This technology is based on the conversion of inorganic nitrogen, especially ammonia, by heterotrophic bacteria into microbial biomass which could then be consumed by the cultured organism, which is aimed to improve water quality and improve feed 
utilization efficiency (Ekasari, 2009). Biofloc technology can be done by adding organic carbon to the maintenance medium to increase the $\mathrm{C} / \mathrm{N}$ ratio and to stimulate the growth of heterotrophic bacteria (Crab et al., 2007). The nutritional quality of biofloc is influenced by, among others, the composition of the biofloc microorganisms (Ekasari et al., 2014).

The positive effects of biofloc system on African catfish production might be explained by three factors, that is, biofloc environment provides good and stable water quality, served as an additional food source for the fish and the environment and consumption improved the fish robustness against stress and disease (Fauji et al., 2018)

According to Bakar et al. (2015), the waste from biofloc technology-cultured catfish could also be utilized as bacterial biomass (flocs) which results in a high growth rate and could improve survival rate. Catfish culture activity usually faces the motile Aeromonas septicemia disease caused by Aeromonas hydrophila which could cause mortality. High density could exacerbate the virulence of the infection. The disease could cause up to $80 \%$ or even $100 \%$ mortality in a relatively short time.

These facts were supported by Lukistyowati and Kurniasih (2012) who stated that the disease outbreak caused by A. hydrophila could cause up to $80-100 \%$ mortality in the fish population in a short time (1-2 weeks). In a biofloc medium, the bacteria Bacillus sp. administered is expected to suppress the growth of this harmful bacteria. This was stated in the study by (Ulkhaq et al., 2014) where the administration of the probiotic Bacillus sp. in catfish dumbo culture was able to suppress the growth of $A$. hydrophila and could result in a $92.23 \%$ survival rate. The present study was aimed to evaluate the production performance of Clarias gariepinus catfish with the administration of probiotic Bacillus sp. in the biofloc technology. The purpose of the current study was to study analyze the production performance of catfish raised using a biofloc system with the addition of Bacillus sp. as decomposing bacteria.

\section{METHODOLOGY}

\section{Place and Time}

This study was conducted in February to June 2018. Fish grow out were carry out in "Unit Pembesaran Kolam Bundar, Bos Lele Semplak Bogor", West Java. Analysis of the effects of pathogenic infections on fish and water contamination worked by Fish Health Laboratory and Fish Environment Laboratory, BDP FPIK IPB, by sending samples.

\section{Research Material}

The materials used in this study were 9 units of $3 \mathrm{~m}$ diameter pool (pond volume $9.2 \mathrm{~m}^{3}$ ), 1 unit trickle filter, scale, hand net, and water tub. The materials used this study was catfish fingerling as much 63,000 fish (ABW $5.9 \mathrm{~g} /$ fish), $63 \mathrm{~m}^{3}$ well water, Bacillus sp. as probiotic, commercial fish feed, and dolomite.

\section{Research Design}

This research is a pre-production trial of catfish culture on an industrial scale using the biofloc system. This study did not use a different treatment plan. In this study all units given the same treatment, as catfish culture in a circular ponds unit with the application of a biofloc system to reach market size.

\section{Work Procedures \\ Media Preparation}

This is not an experimental application but is already an industrial scale, this research is a continuation of previous (Yusuf et al., 2015). Ponds used 9 units of circular tarpaulin material with a metal wire mesh frame $7 \mathrm{~mm}$. Dimensions of the pond were $1.10 \mathrm{~m}$ in height and $3 \mathrm{~m}$ in diameter. Water volume used in each pond of the nine ponds was $5.18 \mathrm{~m} 3$ with the LP 100 Resun aerator, 4 points airstone balls per unit, the water source was well water that had been 
treated in a reservoir using a trickling filter and sedimentation. Ponds were placed indoors with a roof so that they were protected from rainwater and direct sunlight. Ponds are set up with coding K1, $\mathrm{K} 2$, K3, K4, K5, K6, K7, K8, and K9. In this experimental application, all units were gain the same treatment, that was 7000 fish/unit, using the same probiotic, at satiation feeding, and the same sources of water.

\section{Pond Sterilization and Water Filling}

Sterilization was conducted to kill any microorganisms in the ponds, with the expectation that the dominant microorganism to grow was Bacillus sp. Ponds were sterilized by washing using soap and rinsing with water then spraying a $60 \mathrm{ppm}$ chlorine solution to the walls and base of the ponds. The other way is using $30 \mathrm{ppm}$ chlorine that dissolved in water (Panigrahi et al., 2019). After that, the ponds left to dry for one day. Water was channeled into the ponds to a $60 \mathrm{~cm}$ depth and aerated until the smell of chlorine disappeared.

\section{Probiotic Preparation}

Firstly, sterilization of production equipment, then sterilization of raw materials such as pure molasses is heated into a production machine that has been set to a temperature of $100^{\circ} \mathrm{C}$ for 10 minutes, put in a container, and cool at room temperature overnight. Run a contamination test trough molasses sample dilution, Bacillus sp. isolation, and coliform test. If the result was negative continued standard test feasibility of the probiotic bacteria by sample dilution of molasses, bacterial isolated, TPC (Total plate count) test, if it produces minimal 1 $\times 10^{6} \mathrm{CFU} / \mathrm{ml}$ Bacillus sp. (Yusuf et al., 2015) then probiotics are ready to use.

\section{Floc Preparation in the Water in Each Pond}

After the smell of chlorine was gone, the next step, development of the floc, was begun. Sea salt was added to ponds at a dose of $1 \mathrm{~kg} / \mathrm{m}^{3}$, then dolomitic lime $\mathrm{CaMg}\left(\mathrm{CO}_{3}\right)_{2}$ was added at a dose of $10 \mathrm{~g} / \mathrm{m}^{3}$. Finally, a probiotic that contained Bacillus sp. was added at a dose of $10 \mathrm{ml} / \mathrm{m}^{3}$. Ponds were then aerated for 5-7 days for the floc to develop.

\section{Catfish Fingerlings Distribution}

Catfish fingerlings were distributed in the afternoon. Fingerlings were $7-8 \mathrm{~cm}$ long and stocking density was 7000 fish/unit. Before fingerlings were released, they were acclimatized for 15 minutes. After they were released on Day 0 , the catfish fingerlings were not fed for 12 hours and had their behavior observed.

\section{Production of Fermented Feed}

To maintain bacterial homogeneity both in the pond and fish's digestive tract, a feed that containing Bacillus sp. was produced by adding bacteria to feed. The addition was done by mixing $5 \mathrm{ml}$ of the probiotic that contained Bacillus sp. with $200 \mathrm{ml}$ water and stirring until it dissolved. This probiotic solution was then mixed with feed at a dose of $5 \mathrm{ml} / \mathrm{kg}$ feed. The feed is stored in airtight containers. After 3 - 5 days, then fermented feed was ready, marked by the growth of mold.

\section{Maintenance}

Water quality management was conducted morning and afternoon before feeding. The feed (fermented feed) was given in the morning, afternoon, and evening. Probiotic was administered to the maintenance medium at a dose of 10 $\mathrm{ml} / \mathrm{m}^{3}$ every morning $15-30$ minutes after feeding. Fish were not fed for half a day every 7 days, and a sampling of $10 \%$ of the stocking density per unit (weight increase) was conducted every 7 days.

\section{Health and Feed Management}

Fish health management was conducted based on biosecurity principles. If the $\mathrm{pH}$ was low, limewater was added to maintain the stability of the maintenance medium $\mathrm{pH}$. Water was changed every week or if there was a fishy or sulfurous 
odor detected. The volume of water changed was 30-50 \% depending on the fish's condition. Feed was given ad satiation is the feeding method that gives feed as full as possible (Hastuti and Subandiyono, 2014), but if there was a loss of appetite, the feed was reduced or temporarily stopped. The behavior of fish and their physical conditions were observed, especially during feeding time. If any fish demonstrated any signs of illness, it was quickly placed in a separate pond.

Treatment for sick fish was treatment using high-concentration of salt, natural methods using medicinal plants such as the extract of guava leaves, banana pseudostem, betel leaves, and papaya leaves in the maintenance medium, and adding vitamins to feed. Culture equipment was not used shared (nets, water quality measuring tools that are immersed), especially between ponds where there were sick fish or where there had been sick fish to avoid disease crosscontamination.

\section{Tested Parameters}

Growth rate (GR)

Growth rate was calculated following equation Effendie (1997):

$\mathrm{GR}=\mathrm{Wt}-\mathrm{Wo}$

$\mathrm{GR}=$ Growth rate $(\mathrm{g})$

$\mathrm{Wt} \quad=$ Final mean weight $(\mathrm{g})$

Wo: Initial mean weight $(\mathrm{g})$

Specific growth rate

Specific growth rate fish was calculated using the equation as follows:

$$
\begin{aligned}
& \mathrm{SGR}=100 \times \frac{(\ln W \mathrm{t}-\ln W o)}{\mathrm{t}} \\
& \mathrm{SGR}=\text { Specific growth rate }(\%) \\
& \mathrm{Wo}=\text { Initial mean weight }(\mathrm{g}) \\
& \mathrm{Wt}=\text { Final mean weight }(\mathrm{g}) \\
& \mathrm{t} \quad=\text { Culture period (days) }
\end{aligned}
$$

Survival Rate (SR)

At the end of experiment fish were counted to determine the survival and mortality percentage according to following formula (Goddard, 1996):

$$
\begin{aligned}
\mathrm{SR}= & 100 \times \frac{\mathrm{Nt}}{\mathrm{No}} \\
\mathrm{SR}= & \text { Survival Rate (\%) } \\
\mathrm{Nt}= & \begin{array}{l}
\text { Number of fish at the end of } \\
\text { experiment (fish) }
\end{array} \\
\mathrm{No}= & \begin{array}{l}
\text { Number of fish at the beginning of } \\
\text { experiment (fish) }
\end{array}
\end{aligned}
$$

Feed conversion ratio (FCR)

$$
\begin{aligned}
& \text { FCR }=\frac{\text { Total Feed }}{\text { Total Biomass }} \\
& \begin{array}{ll}
\text { FCR } & \text { Feed conversion ratio } \\
\text { Total feed } & \text { Total amount of feed } \\
& \text { during culture period }(\mathrm{kg}) \\
\text { Total Biomass } & =\text { Total harvest biomass }(\mathrm{kg})
\end{array}
\end{aligned}
$$

\section{Data Analysis}

Production performance parameters include weight growth, growth rate (GR), specific growth rate (SGR), and survival rate (SR) referring to the Solanki et al. (2012), and the feed conversion ratio (FCR) refers to Yusuf et al. (2015). Growth was observed by sampling at weeks 0,1 , $2,3,4,5,6,7,8,9,10$, and 11 of culture. Once the results were obtained, the data were analyzed using descriptive analysis and then presented in tables and figures using Ms. Excel.

\section{RESULTS AND DISCUSSION Production Performance}

During the study, measurement of growth performance parameters which included absolute growth rate (GR), specific growth rate (SGR), survival rate (SR), and feed conversion ratio (FCR) were measured. The average growth rate results are presented in Figure 1. 


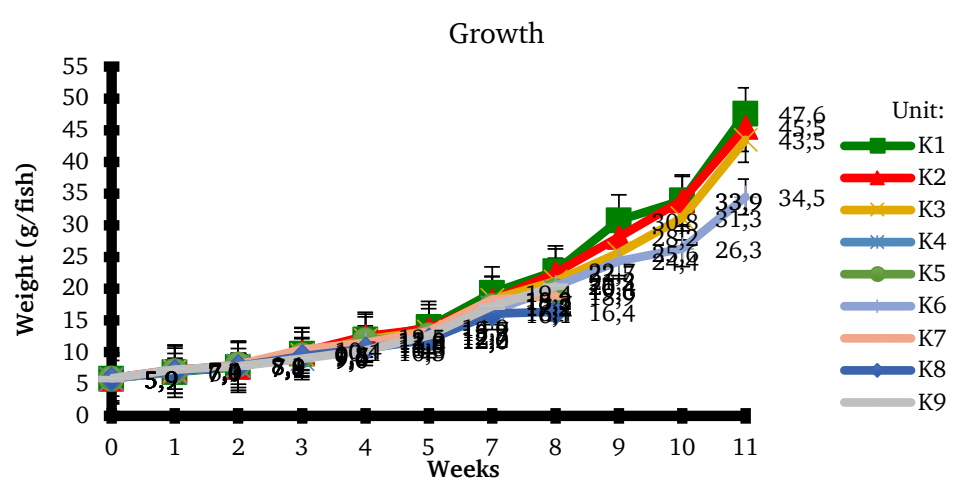

Figure 1. Average growth rate of catfish during culture of 11-week.

According to Figure 1. its showed that average catfish weight increased weekly. Fish's initial average weight at the beginning of the culture period was $5.9 \pm$ $0.0 \mathrm{~g} /$ fish with a density of $7000 \mathrm{fish} /$ pond in 9 units of circular ponds with biofloc technology system culture, resulting in different growth rates on different culture periods. The culture of fish in ponds $\mathrm{K} 1$, $\mathrm{K} 2, \mathrm{~K} 3$, and $\mathrm{K} 6$ were chosen to be extended because their growth evaluation results were better than those fish in ponds $\mathrm{K} 4, \mathrm{~K} 5, \mathrm{~K} 7, \mathrm{~K} 8$, and $\mathrm{K} 9$ after a disease outbreak. The daily growth rate K1, K2, K3 and $\mathrm{K} 6$ were $0.14 \mathrm{~g} /$ day, $0.13 \mathrm{~g} /$ day, 0.13 $\mathrm{g} /$ day, and $0.10 \mathrm{~g} /$ day this result relatively higher than previous study (Soedibya et al., 2017), produce results $0.09 \pm 0.02$ $\mathrm{g} /$ day, $0.13 \pm 0.06 \mathrm{~g} /$ day $0.10 \pm 0.04 \mathrm{~g} /$ day and $0.10 \pm 0.03 \mathrm{~g} /$ day.
Therefore, fish in ponds K4, K5, K7, $\mathrm{K} 8$, and $\mathrm{K} 9$ were harvested early, as a result of mass mortality. This outbreak was caused by Aeromonas hydrophila. According to Lukistyowati and Kurniasih (2012), these bacteria cause disease outbreaks with high mortality rates (80$100 \%)$ in a short time (1-2 weeks). Virulence level of $A$. hydrophila which can cause mass death.

The highest final weight was demonstrated by ponds K9 (20.4 \pm 5.1 $\mathrm{g} /$ fish), K4 and K5 (19.6 $\pm 4.9 \mathrm{~g} /$ fish), K7 $(18.9 \pm 4.9 \mathrm{~g} / \mathrm{fish})$, and $\mathrm{K} 8$ (16.4 \pm 4.0 $\mathrm{g} /$ fish) with a 9 week culture period. Then, K1 (47.6 $\pm 13.4 \mathrm{~g} /$ fish), K2 (45.5 \pm $12.6 \mathrm{~g} / \mathrm{fish}), \mathrm{K} 3$ (43.5 $\pm 11.8 \mathrm{~g} / \mathrm{fish})$, and K6 (34.5 $\pm 9.3 \mathrm{~g} / \mathrm{fish})$ with a culture period of 11 weeks. The growth rate is presented in Figure 2.

\section{Growth Rate (GR)}

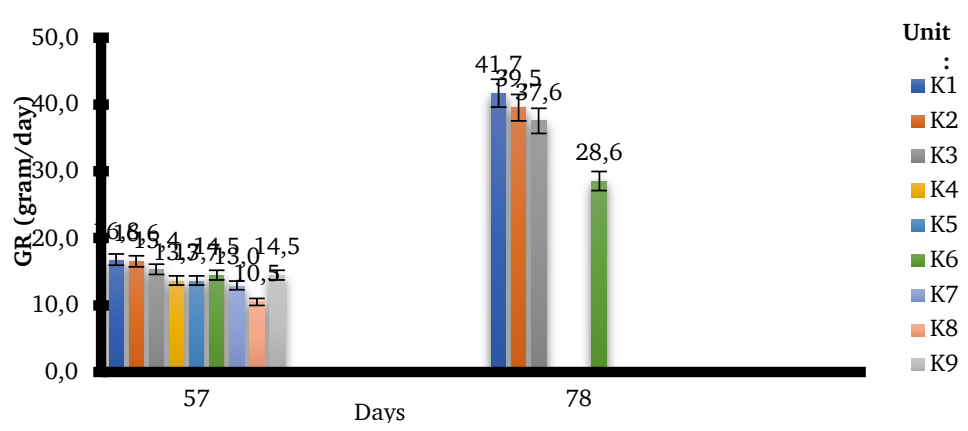

Figure 2. Absolute growth (growth rate) of catfish during 57-day and 78-day culture periods .

As presented in Fig. 2, the growth rate of catfish during the 57-day culture period, and the highest results were demonstrated by fish in ponds K1 (16.8 \pm
1.9 g/day), K2 (16.6 $\pm 1.9 \mathrm{~g} /$ day $), \mathrm{K} 3$ (15.4 $\pm 1.9 \mathrm{~g} /$ day), K6 (14.5 \pm 1.9 g/day), K9 (14.5 $\pm 1.9 \mathrm{~g} /$ day), K4 and K5 $(13.7 \pm 1.9 \mathrm{~g} /$ day $), \mathrm{K} 7(13.0 \pm 1.9$ 
g/day), K8 (10.5 \pm 1.9 g/day), respectively. Then, extended culture period for 78 days resulted in the highest growth rate in $\mathrm{K} 1(41.7 \pm 5.8 \mathrm{~g} /$ day $), \mathrm{K} 2$ $(39.5 \pm 5.8 \mathrm{~g} /$ day $), \mathrm{K} 3 \quad(37.6 \pm 5.8$ g/day), and K6 (28.6 $\pm 5.8 \mathrm{~g} /$ day), respectively. The results of this experiment showed that growth rate is smaller than results obtained by Putra et al. (2017) which can obtain growth in the range of $1.6 \pm 0,28 \mathrm{~g} /$ day, whereas this study only gets daily growth $0.54 \pm 0,27 \mathrm{~g} /$ day.

It can be caused by a lack of carrying capacity. Factors that affect the carrying capacity include water quality, feed, and the size of the fish. Space and food supply are factors that also affect the growth of fish, where the fish will grow better if both factors can be met, and otherwise growth will slow if one or both are lacking. This result indicated that biofloc was able to increase growth (Soedibya et al., 2018).

The lower growth rate in this study is suspected of high density, increasing fish density may compromise animal welfare, which reduces survival and growth. Adverse effects of high density on fish production have been recorded in many aquaculture species mostly attributed to stress (van de Nieuwegiessen et al., 2009), it caused by the deterioration of water quality and competition for space and food. In addition to growth rate, can also be measured based on $\%$ daily growth i.e. with specific growth methods. The specific growth rate can be seen in Figure 3.

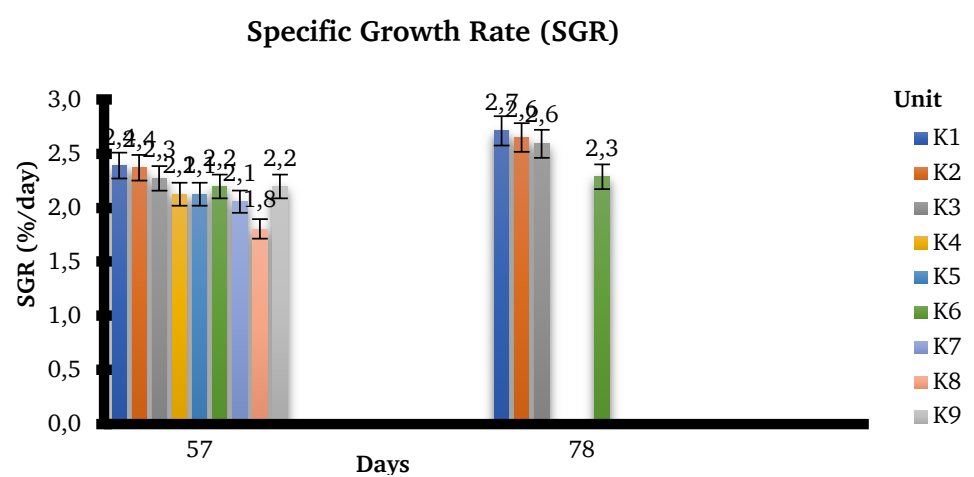

Figure 3. Specific growth rate of catfish during 57-day and 78-day culture period.

Specific growth rate (SGR) of catfish during the 57-day culture period and the highest results were demonstrated by fish in pond $\mathrm{K} 1$ and $\mathrm{K} 2(2.4 \pm 0.2 \%$ /day $), \mathrm{K} 3$ $(2 / 3 \pm 0.2 \%$ /day), K6 and K9 (2.2 \pm 0.2 $\%$ /day), K4, K5, K7 (2.1 $\pm 0.2 \%$ /day), and K8 (1.8 $\pm 0.2 \%$ /day), respectively, this result higher than previous studies where the gain on 50 days biofloc treatment were 0.87-1.15 \%/day (Soedibya et al., 2017). According to Ekasari et al. (2016), the addition of Bacillus sp., cells into feed had a positive impact on the fish digestive system due to exogenous enzymes released by cells. Furthermore, for extended culture, which was 78 days, the results were $\mathrm{K} 1(2.7 \pm$ $0.2 \%$ /day), K2 and K3 (2.6 $\pm 0.2 \%$ /day), and K6 (2.3 $\pm 0.2 \%$ /day), respectively. This result relatively higher than Soedibya et al. (2018) which gets average results $1.04 \pm 0.12 \% /$ day.

Contrasts with Soedibya et al. (2018) who state that wide space enough to make the fish a lot of activities so that a lot of energy used for activity and metabolic processes than for growth, in this study showed that lower stocking density (1300 fish $/ \mathrm{m}^{3}$ ) produce relatively higher SGR. The survival rate parameter can be seen in Figure 4. 
Survival Rate (SR)

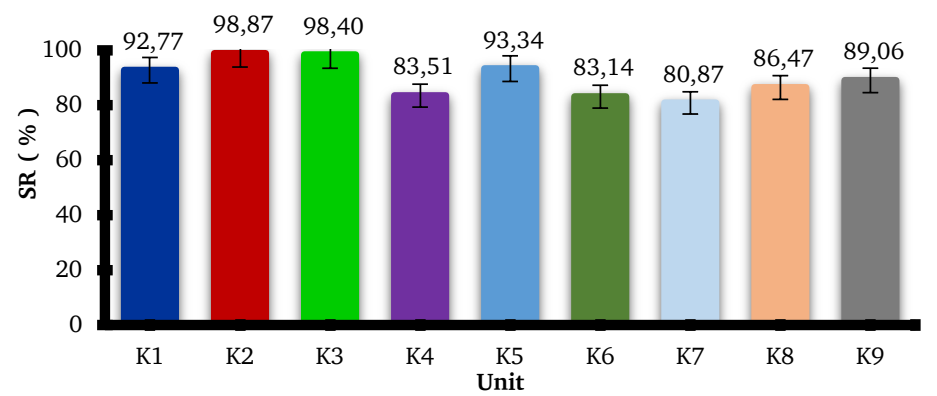

Figure 4. Survival rate of Catfish's during culture period.

Figure 4 shows the survival rate of catfish during the culture period, and the highest results in the first harvest were demonstrated by fish in ponds $\mathrm{K} 5$ (93.34 $\pm 6.64 \%)$, K9 $(89.06 \pm 6.64 \%)$, K8 $(86.47 \pm 6.64 \%), \mathrm{K} 4(83.51 \pm 6.64 \%)$, and $\mathrm{K} 7(80.87 \pm 6.64 \%)$, respectively. Meanwhile, for the second harvest, highest results were demonstrated by fish in ponds K2 (98.87 $\pm 6.64 \%), \mathrm{K} 3(98.40$ $\pm 6.64 \%)$, K1 (92.77 $\pm 6.64 \%)$, and $\mathrm{K} 6$ $(83.51 \pm 6.64 \%)$, respectively. Administration of Bacillus sp. probiotics at a dose of $104 \mathrm{cfu} / \mathrm{mL}$ can effectively suppress the growth of Aeromonas hydrophila and prevent MAS disease by increasing immune response and survival of African catfish (Ulkhaq et al., 2014).

The percentage survival of Clarias gariepinus cultured was generally high (80.87\% to $98.87 \%)$. High percentage survival is attributed to air-breathing and relatively high tolerance of $C$. gariepinus to poor water quality conditions. This results in line with Shoko et al. (2016) that get results $95.42 \%$ to $98.83 \%$ survival rate.

Feed Conversion Ratio (FCR)

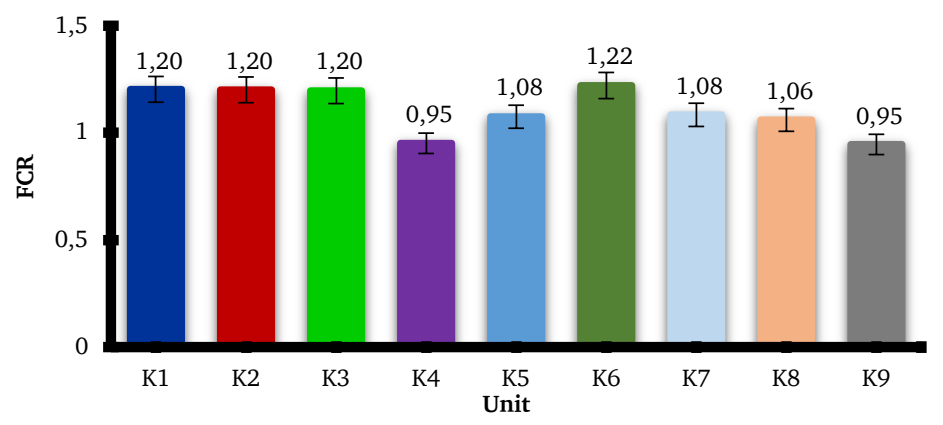

Figure 5. Feed conversion ratio of catfish during culture period.

Figure 5 showed the best feed conversion ratio for catfish during the course of the study, ranked for the first harvest as follows: fish in ponds $\mathrm{K} 4$ and $\mathrm{K} 9$ (0.95 \pm 0.11$), \mathrm{K} 8(1.06 \pm 0.11), \mathrm{K} 5$ and K7 (1.08 \pm 0.11). Meanwhile, for the second harvest, they were fish in ponds $\mathrm{K} 1, \mathrm{~K} 2, \mathrm{~K} 3(1.20 \pm 0.11)$, and K6 (1.22 \pm $0.11)$. This result relatively similar compared with the prior study, where the Feed conversion ratio of catfish grown in biofloc culture 0.91-1.42 (Yusuf et al., 2015).
Besides accelerate growth, biofloc is also had an important role as an alternative natural feed. This is because the biofloc contains a crude protein that reached 48-53\% (Hastuti and Subandiyono, 2014) and therefore the Feed Conversion Ratio (FCR). According to Putra et al. (2017) produce an efficiency of 0.9 (below 1.00). This study results in relatively the same, where the FCR is in range 0.9-1.22. This is because besides fed on the commercial diet, the fish was also fed on floc that contains planktons. This 
value is better than fish fed on a commercial diet without the application of biofloc (Jimoh et al.,2014). According to Azim et al. (2007), the nutritional quality of biofloc was appropriate at least for herbivorous and omnivorous fish species. In this field, the African catfish is categorized as omnivorous feeding habits (Rad et al., 2004).

Water reservoir capacity of $20 \mathrm{~m}^{3}$ can fill 4 ponds in one charge, to fill entire ponds require $46.2 \mathrm{~m}^{3}$ or 2,33 times from reservoir capacity. Water in the reservoir had a hardness value of $33.90 \mathrm{mg} / \mathrm{L}$, whereas the optimum range is $50-200$ $\mathrm{mg} / \mathrm{L}$ at a $\mathrm{pH}$ of $6.5-9.0$. Hardness is a measurement of the amount of calcium (Ca) and magnesium ( $\mathrm{Mg}$ ) salts that play an important role in maintaining fish's environmental quality, supporting calcium supply needed for the construction of bones, and reducing osmotic performance needed to replace blood electrolytes which are constantly lost through urine in large amounts. Iron $(\mathrm{Fe})$ content in the reservoir water was $0.011 \mathrm{mg} / \mathrm{L}$, while the optimum range is $0.00-0.05 \mathrm{mg} / \mathrm{L}$. (Ogbonna and Chinomso, 2010). A high Fe content could reduce the quality of Bacillus sp. bacteria abundance which is why the Fe content in the water must be kept at a minimum.

Total ammonia total $\left(\mathrm{NH}_{3}\right)$ content of healthy fishpond water was $1.371 \mathrm{mg} / \mathrm{L}$ and the sick fishpond was $0.323 \mathrm{mg} / \mathrm{L}$, whereas the optimum is $\mathrm{NH}_{3} \leq 0.01 \mathrm{mg} / \mathrm{L}$. Nitrite $\left(\mathrm{NO}_{2}\right)$ content of healthy fish pond water was $0.001 \mathrm{mg} / \mathrm{L}$ and sick fish pond was $0.268 \mathrm{mg} / \mathrm{L}$, whereas optimum is $\mathrm{NH}_{2}$ $\leq 0.1 \mathrm{mg} / \mathrm{L}$. Visually, sick fish had bloated, yellowish-red bodies which are signs of ammonia poisoning in fish.
Ammonia and nitrite are toxic to fish because when the environment or pond water is too saturated with ammonia, fish are unable to release ammonia from their bodies in the form of urine or feces, causing fish to be poisoned by internal ammonia. Ammonia is generally toxic to fish (Shiwanand and Tripathi, 2013) when reaching out of $1.5 \mathrm{mg} / \mathrm{L}$ (Yusoff et al., 2011). The concentration of $2 \mathrm{mg} / \mathrm{L}$ nitrite causes a slow growth rate of fish and 4 $\mathrm{mg} / \mathrm{L}$ causes acute death (Yusoff et al., 2011). The acute concentration of nitrite in yellow catfish (Pelteobagrus fulvidraco) sized $0.029 \pm 0.049 \mathrm{~g}$ was $8.74 \mathrm{mg} / \mathrm{L}$ (Zhang et al., 2012), while nitrite content of $3.92 \mathrm{mg} / \mathrm{L}$ lowered daily growth rate below $2 \%$ in African catfish (C. gariepinus) (Roques et al., 2015).

Relatively low hardness in the water reservoir could be corrected by applying $\mathrm{CaO}$ or $\mathrm{CaCO}_{3}$ at a dose of 10-160 ppm. The best dose for growth and survival of Indian carp Labeo rohita is 150 ppm (Rajkumar et al., 2018). While a high Fe content could be corrected by using filter substrates (zeolite, volcanic sand, activated charcoal, and bioballs) and aeration in the reservoir. The filtering system can be designed in a trickle filter system where the filter substrates are placed inside containers which are then stacked.

Water flowing from the well is passed through the containers containing filter substrates and into a reservoir tank. The volume of the reservoir was $60 \mathrm{~m} 3$ so the required filter system was $20 \mathrm{~m} 3 /$ filter container for each type of filter material used, as seen in Figure 6. 

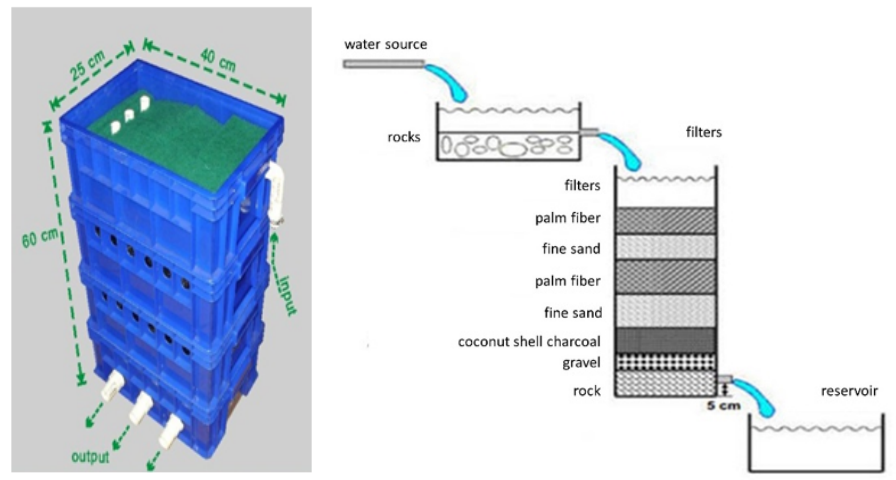

Figure 6. System of reservoir water filtering.

High ammonia and nitrite contents in healthy and sick fishponds could be corrected when Bacillus sp. bacteria which has an important role in the culture of fish using biofloc system work effectively, where the optimum abundance which is $\geq$ $1 \times 10^{6} \mathrm{CFU} / \mathrm{ml}$ is reached. Additionally, a water replacement system where at least $10 \mathrm{~cm}$ is replaced daily needs to be done, and removal of sediments on the floor of the pond before every feeding to minimize the content of toxic organic materials in the maintenance medium is important.

\section{CONCLUSION}

Fish growth increased in size at every sampling but it was very slow due to a disease outbreak. In addition, the water source was contaminated with bacteria and had a high iron $0.011 \mathrm{mg} / \mathrm{L}$, while the optimum range is $0.00-0.05 \mathrm{mg} / \mathrm{L}$, it causing less than optimum growth of probiotic bacteria, so fish culture system with a high stocking density potentially led to stress, illness, inhibited growth, and even mass mortality.

\section{ACKNOWLEDGEMENT}

The authors thank to Mr. Amrit Lakhiani CEO of PT. Jaya Properti Indonesia as the owner and investor, Mrs. Peni Syanti "Bos Lele Semplak Bogor", and "Kelola Mina Pembudidaya Jogjakarta" team as executors and researchers.

\section{REFERENCES}

Azim, M.E., Little, D. and North, B., 2007. Growth and welfare of Nile tilapia
(Oreochromis niloticus) cultured indoor tank using biofloc technology (BFT). In Procedings of Aquaculture Conference 2007 (Vol. 26).

Bakar, N.S.A., Nasir, N.M., Lananan, F., Hamid, S.H.A., Lam, S.S. and Jusoh, A., 2015. Optimization of $\mathrm{C} / \mathrm{N}$ ratios for nutrient removal in aquaculture system culturing African catfish,(Clarias gariepinus) utilizing Bioflocs Technology. International Biodeterioration \& Biodegradation, 102, pp.100-106. https://doi.org/1 0.1016/j.ibiod.2015.04.001.

Crab, R., Avnimelech, Y., Defoirdt, T., Bossier, P. and Verstraete, W., 2007. Nitrogen removal techniques in aquaculture for a sustainable production. Aquaculture, 270(1-4), pp.1-14. https://doi.org/10.1016/j. aquaculture.2007.05.006.

Direktorat Jenderal Perikanan Budidaya. 2016. LAKIN: Laporan Kinerja 2016. Retrieved from http://kinerjaku. kkp.go.id/2018/dok/lkj/04_LKj_DJ PB_2016.pdf.

Effendie, M.I., 1997. Biologi perikanan. Yayasan Pustaka Nusatama. Yogyakarta.

Ekasari, J. 2009. Teknologi Biotlok: Teori dan Aplikasi dalam Perikanan Budidaya Sistem Intensif Bioflocs Technology: Theory and Application in Intensive Aquaculture System. Jurnal Akuakultur Indonesia, 8(2), pp.117-126. https:/ /doi.org/10.19027/jai.8.117-126

Ekasari, J., Azhar, M.H., Surawidjaja, E.H., Nuryati, S., De Schryver, P. 
and Bossier, P., 2014. Immune response and disease resistance of shrimp fed biofloc grown on different carbon sources. Fish \& shellfish immunology, 41 (2), pp.332339. https://doi.org/10.1016/j.fsi. 2014.09.004.

Ekasari, J., Suprayudi, M.A., Wiyoto, W., Hazanah, R.F., Lenggara, G.S., Sulistiani, R., Alkahfi, M. and Zairin Jr, M., 2016. Biofloc technology application in African catfish fingerling production: the effects on the reproductive performance of broodstock and the quality of eggs and larvae. Aquaculture, 464, pp.349-356. https://doi.org/10.101 6/j.aquaculture.2016.07.013.

Fauji, H., Budiardi, T. and Ekasari, J., 2018. Growth performance and robustness of African Catfish Clarias gariepinus (Burchell) in bioflocbased nursery production with different stocking densities. Aquaculture Research, 49(3), pp.1339-1346. https://doi.org/10.1 111/are.13595

Hastuti, S. and Subandiyono, 2014. Production Performance of African Catfish (Clarias gariepinus, burch) were Rearing with Biofloc technology. SAINTEK PERIKANAN: Indonesian Journal of Fisheries Science and Technology, 10(1), pp.37-42. https://doi.org/10.14710 /ijfst.10.1.37-42

Jimoh, W.A., Fagbenro, O.A. and Adeparusi, E.O., 2014. Response of African catfish, Clarias gariepinus (Burchell 1822), fingerlings fed diets containing differently timed wet-heat-treated sesame (Sesamum indicum) seedmeal. Agricultural Sciences, 5(12), p.1159-1171. 10. 4236/as.2014.512126.

Lukistyowati, I. and Kurniasih, 2012. Pelacakan Gen Aerolysin dari Aeromonas hydrophila pada Ikan Mas yang Diberi Pakan Ekstrak Bawang Putih. Jurnal Veteriner, 13(1), pp.43-50. https://ojs.unud. ac.id/index.php/jvet/article/view/2 137

Ogbonna, J. and Chinomso, A., 2010. Determination of the concentration of ammonia that could have lethal effect on fish pond. Journal of Engineering and Applied Sciences (Asian Research Publishing Network), 5, pp.1-5. https://citeseerx.ist.psu. edu/viewdoc/download?doi=10.1. 1.629.5108\&rep $=$ rep $1 \&$ type $=$ pdf

Putra, I., Rusliadi, R., Fauzi, M., Tang, U.M. and Muchlisin, Z.A., 2017. Growth performance and feed utilization of African catfish Clarias gariepinus fed a commercial diet and reared in the biofloc system enhanced with probiotic. F1000Research, 6(1545). https://do i.org/10.12688/f1000research.124 38.1 .

Panigrahi, A., Sundaram, M., Chakrapani, S., Rajasekar, S., Syama Dayal, J. and Chavali, G., 2019. Effect of carbon and nitrogen ratio $(\mathrm{C}: \mathrm{N})$ manipulation on the production performance and immunity of Pacific white shrimp Litopenaeus vannamei (Boone, 1931) in a biofloc-based rearing system. Aquaculture Research, 50(1), pp.2941. https://doi.org/10.1111/are.13 857.

Rad, F., Kurt, G. and Bozaoğlu, A.S., 2004. Effects of spatially localized and dispersed patterns of feed distribution on the growth, size dispersion and feed conversion ratio of the African Catfish (Clarias gariepinus). Turkish Journal of Veterinary and Animal Sciences, 28(5), pp.851-856. https://journals. tubitak.gov.tr/veterinary/abstract.h $\mathrm{tm}$ ?id $=7213$

Rajkumar, K., Ojha, M.L., Saini, V.P. and Sharma, S.K., 2018. Effect of water hardness on survival and growth of Labeo rohita (Hamilton) fry. Journal of Entomology and Zoology Studies, 6(5), pp.2337-2341. https://www. researchgate.net/profile/V_P_Saini /publication/328477770_Effect_of_ 
water_hardness_on_survival_and_g rowth_of_Labeo_rohita_Hamilton_f ry/links/5 bd04c 22299 bf1a43d9cbd $5 \mathrm{~b} /$ Effect-of-water-hardness-onsurvival-and-growth-of-Labeorohita-Hamilton-fry.pdf

Roques, J.A., Schram, E., Spanings, T., van Schaik, T., Abbink, W., Boerrigter, J., de Vries, P., van de Vis, H. and Flik, G., 2015. The impact of elevated water nitrite concentration on physiology, growth and feed intake of African catfish Clarias gariepinus (Burchell 1822). Aquaculture Research, 46(6), pp.1384-1395. https://doi.org/10. 1111/are.12292

Shiwanand, A. and Tripathi, G., 2013. A Review on Ammonia Toxicity in Fish. Asia Pacific Journal of Life Sciences, 7(2), p.193. https:// search.proquest.com/openview/70b d6b43280cbade7dbe7fa5997ce20b $/ 1$ ?pq-origsite $=$ gscholar $\& \mathrm{cbl}=$ 2034814

Shoko, A.P., Limbu, S.M. and Mgaya, Y.D., 2016. Effect of stocking density on growth performance, survival, production, and financial benefits of African sharptooth catfish (Clarias gariepinus) monoculture in earthen ponds. Journal of Applied Aquaculture, 28(3), pp.220-234. https://doi.org/10.1080/10454438 .2016 .1188338

Soedibya, P.H.T., Pramono, T.B. and Listiowati, E., 2017. Growth performance of African catfish Clarias gariepinus cultured in biofloc system at high stocking density. Jurnal Akuakultur Indonesia, 16(2), pp.244-252. https ://doi.org/10.19027/jai.16.2.255263.

Soedibya, P.H.T., Listiowati, E., Pramono, T.B., Prayogo, N.A. and Harisam, R.T., 2018. Growth Performance of Catfish (Clarias gariepenus) Cultured of High Density with Biofloc System. In E3S Web of Conferences (Vol. 47, p. 02002). EDP
Sciences. https://doi.org/10.1051/ e3sconf/20184702002.

Solanki, Y., Jetani, K.L., Khan, S.I., Kotiya, A.S., Makawana, N.P. and Rather, M.A., 2012. Effect of stocking density on growth and survival rate of Spiny Lobster (Panulirus polyphagus) in cage culture system. Int. J. of Aquatic Science, 3(1), pp.314. https://www.researchgate.net/ profile/Anil_Kotia/publication/216 459173_Effect_of_stocking_density _on_growth_and_survival_rate_of_ Spiny_Lobster_Panulirus_polyphag us_in_cage_culture_system/links/0 d1c84f6c0ae63845b000000.pdf

Sukenda, W., Widanarni and Setiawati, M., 2016. Respons imun dan kinerja pertumbuhan ikan lele, Clarias gariepinus (Burchell 1822) pada budi daya sistem bioflok dengan sumber karbon berbeda serta diinfeksi Aeromonas hydrophila. Jurnal Iktiologi Indonesia, 16(3), pp.309-323. https://doi.org/10.324 91/jii.v16i3.30

Ulkhaq, M.F., Widanarni and Kusumastuti, A.M., 2014. Application of Bacillus probiotic to prevent Aeromonas hydrophilla infection in Clarias sp. Jurnal Akuakultur Indonesia, 13(2), pp.105-114. https://doi.org/10.190 27/jai.13.105-114

van de Nieuwegiessen, P.G., Olwo, J., Khong, S., Verreth, J.A. and Schrama, J.W., 2009. Effects of age and stocking density on the welfare of African catfish, Clarias gariepinus Burchell. Aquaculture, 288(1-2), pp.69-75. https://doi.org/10.1016/ j.aquaculture.2008.11.009.

Yusoff, F.M., Banerjee, S., Khatoon, H. and Shariff, M., 2011. Biological approaches in management of nitrogenous compounds in aquaculture systems. Dyn Biochem Process Biotech Mol Biol, 5, pp.21-31. http://www.globalsciencebooks.inf o/Online/GSBOnline/images/2011 /DBPBMB_5(SI1)/DBPBMB_5(SI1) 21-31o.pdf 
Yusuf, M.W., Utomo, N.B.P. and Yuhana, M., 2015. Growth Performance of Catfish (Clarias gariepinus) in Biofloc-Based Super Intensive Culture Added with Bacillus sp. Journal of Fisheries and Aquatic Science, 10(6), p.523-532. https://d oi.org/10.3923/jfas.2015.523.532.

Zhang, L., Xiong, D.M., Li, B., Zhao, Z.G., Fang, W., Yang, K. and Fan, Q.X., 2012. Toxicity of ammonia and nitrite to yellow catfish (Pelteobagrus fulvidraco). Journal of Applied Ichthyology, 28(1), pp.8286. https://doi.org/10.1111/j.1439 $-0426.2011 .01720 . x$ 